\title{
Agri-Business Lending and Economic Transformation in Rwanda:Case Study of BPR Agri-Business Loans in Rwamagana District
}

\author{
Habimana Djamal ${ }^{1}$, Dr. Claude Rusibana ${ }^{2}$ and Machila Mwangi ${ }^{3}$ \\ ${ }^{1,2,3}$ Researcher, Mount Kenya University, \\ Kigali, Rwanda
}

\begin{abstract}
Despite the significant growth in the Rwanda banking sector, few loans have specialized in agriculture financing except agriculture guarantees and other guarantee fund helping access to bank and microfinance credits farmers despite the fact that agriculture has been described as the key driver of sustainable economic transformation in contributing to the country's GDP. Rwandan farmers have been requesting an agricultural development bank to be created in order to cater for the credit needs of farmers, microfinance institutions and cooperatives that credit facilities at high interest rates which is a key barrier on the side of the smallholder farmers and the nature of the sector on the other side. The general objective of the study was to examine the contribution of agri-business lending on economic transformation in Rwanda, taking BPR AgriBusiness lending in Rwamagana District as the case study. The specific objectives of the study were; to assess the contribution of BPR's farm loans on economic transformation of Rwamagana District; to evaluate the contribution of BPR's Agri-business cash advances on economic transformation of Rwamagana District; to assess the contribution of BPR's direct farm ownership loan on economic transformation of Rwamagana District; and to examine the relationship between BPR's agribusiness lending and economic transformation of Rwamagana District. The study used descriptive and correlation research designs. The target population of the study was 633 farmers servicing agri-business loans at BPR Atlasmara Branch in Rwamagana District and 4 credit managers located at the branch. The sample size $n=84$ was calculated using bouchar formula. Purposive and systematic sampling techniques were used to select respondents. Primary data was collected using a survey questionnaire and an interview guide while secondary data was sourced
\end{abstract}

from published and unpublished sources from the library and peer-reviewed articles from journals. Questionnaires were checked for errors and those found erroneous excluded from the final set to be analyzed. Accurately completes questionnaire were then coded and entered into the Statistical Packages for Social Sciences (SPSS) - Version 23 software for analysis. Data was analyzed using descriptive statistics in frequencies, percentages, standard deviations, and means. Correlation and regression analysis to determine the relationship between study variables. Respondents agreed that BPR's farm loans had contributed to the economic transformation of Rwamagana by; reducing poverty (mean 4.27, sdv .78 ); increasing productivity (mean 4.39, sdv .83); increasing asset acquisition (mean 4.29, sdv.65); increasing cash flows (mean 4.29; sdv .80); increasing savings (mean 4.34, sdv .64); enhancing health and nutrition (mean 4.14, sdv .99); improving food security (mean 4.32; sdv .73); increasing employment opportunities (mean 4.50, sdv .69); and improving infrastructure (mean 4.17; sdv 1.16). Findings from the correlation analysis suggested positive correlations between farm loans and; poverty reduction $(\mathrm{r} .972 * *, \mathrm{p} .000)$, increase in productivity (r. .254*, p .019), and Increase in agriculture cash flows ( $\mathrm{r} .265^{*}, \mathrm{p} .045$ ); Agribusiness cash advances and; poverty reduction ( $\mathrm{r}$ $.747^{*}, \mathrm{p} .036$ ), increase in productivity ( $\mathrm{r} .971^{* *}, \mathrm{p}$ .000 ), and Increase in agriculture cash flows (r. $.945^{* *}, \mathrm{p} .000$ ); and Direct farm ownership loan and; poverty reduction $(\mathrm{r} .572 *, \mathrm{p} .015)$, increase in productivity ( $\left.\mathrm{r} .579^{* *}, \mathrm{p} .000\right)$, and Increase in agriculture cash flows (r. .775*, p .032). All the correlations were statistically significant given that the $p$ value was $<0.05$ and $<0.01$. The findings from regression analyses suggested that all the dependent variables (poverty reduction, increase in productivity, and Increase in agriculture cash flows) 
met the assumptions and there was no first order linear auto-correlation in the data, hence, the models were significant in predicting the influence of BPR's agri-business lending on the depended variables given that the $\mathrm{p}$ values were $<0.05$ and $<0.01$. The study concluded that there was a positive relationship between BPR agriculture related credit facilities and agricultural production and poverty eradication. The study recommended that BPR and other relevant financial institutions to formulate credit plans aimed at targeting consumers in the agricultural sector.

\section{Introduction}

From a global perspective, the banking system is looking for ways to finance the value chain in agriculture and the businessoriented production especially rice, maize and soy beans. It is cooperative responsibility to collect the production of all members and sell them to third parties. The main focus in agri-business financing in global perspective is to finance farmers who are driven by knowledge in field, science and technology (McIntyre, 2018). These have had resulted in the financial need in selected seeds that can respond to the world need in terms of food security, irrigation to solve water problem in most cases of SSA, and climate change as well as setting up the infrastructure that may connect farmers to the financial institutions. As per today, agricultural finance is focusing on the value chain finance especially in crops and cereal. The reasons behind are the benefit of co-management of the whole system until the end which makes easy monitoring and risk evaluation. Cooperatives banks and microfinance lending institutions also are the key to focusing on agri-business financing mostly in SubSaharan countries especially East African Community including Rwanda, Kenya, Tanzania, and Uganda.

The economy of Rwanda is to a major part based on rain-fed semi-substance and small-scale agricultural production. It has a small deposit of natural resources the country can exploit and an uncompetitive, small industrial sector. Households cultivating land that is 0.7 ha or less are more than $60 \%$ of the population with more than $25 \%$ cultivating less than 0.2 ha. The living standards are defined by the agricultural holding size, consequently the poorest households are those that possess the smallest land (Rwanda agriculture Report, 2011). A third of the GDP of Rwanda is accounted for by agriculture. It is the primary wellspring of job for families in the provincial territories (mainly women). Rwanda's Economic transformation and Poverty Reduction Strategy (EDPRS) spells out numerous agricultural programs with the inclusion of intensification of production systems that are sustainable in animal husbandry and cultivation of crops; building

\section{ISSN 2455-6378}

organizational and technical farmer capacity, promotion of agribusiness and chains of commodities. The main problem in the achievement of these aims is insufficient financial resources.

Rwanda is among African countries that attract high percentages of foreign investors due to its fast growing economy. The access to finance is easy because more than $90 \%$ of the adult population reside within a 5 kilometers radios from financial institutions and no more barriers related to eligibility to access for finance as well as minimum deposit and balance. A survey by Finiscope Rwanda (2012) rated the financial inclusion of adult Rwandese at $72 \%$, with $42 \%$ being formally served by commercial and non-formal financial institutions (Access to Finance Rwanda, 2013). This steady growth of Rwandan to access for banking service serves to highlight the big opportunity to design the separate agricultural financing to that market niche due to its steady growth 5.8\% GDP between 2000-2012 (Stone, Temu, Kalisa, \& Cabello, 2011). Furthermore, there are a lot of grants for this particular sector that have to be well channeled. However, despite a significant growth in the Rwanda banking sector, few loans have specialized in agriculture financing except agriculture guarantees and other guarantee fund helping access to bank and microfinance credits farmers despite the fact that agriculture has been described as the key driver of sustainable economic transformation in contributing to the country's GDP. BPR offers lending support to farmers with the aim of developing horticulture and food crop production in the District, which has led to increased rice productivity.

\subsection{Statement of the Problem}

Cyaruhogo marshland is among the first developed cultivation area in Rwamagana District that has been enhanced by the government to offer constant water for irrigation. Specifically designed to enhance rice farming in the district, farmers in the marshland have turned out to financial institutions for financing. In a bid to empower farmers, BPR has devised products accessed as loans by farmers in Rwamagana district while using their harvest as guarantee. Rice is among the produce accepted as guarantee because it takes longer to perish than other agricultural products. Farmers' harvest is stored warehouses for some time until the loan is repaid. In the meantime, the bank also works with responsible cooperatives in locating markets for the produce. Farmers applying for loans as cooperatives are given more money compared to those that apply individually, who are actually given half of the loans offered to those applying through cooperatives. Rwandan farmers have been requesting for the founding of an agricultural development bank resulting from thorough and restrictive terms to access credit from business banks, microfinance 
institutions and cooperatives that credit facilities at high interest rates which is a key barrier on the side of the smallholder farmers and the nature of the sector on the other side (Stone, Temu, Kalisa, \& Cabello, 2011). For a sector that accounts for 30 per cent of the country's GDP and employs about 70 per cent Rwandans, farmers contend that agriculture needs a special bank to unlock its potential. Thus, the financing trend of the sector leaves some gaps and lots to be desired, and hence prompting the researcher into examining the contribution of agribusiness lending to the economic transformation of Rwanda; taking rice farmers in Rwamagana District as the case study.

\subsection{Objectives of the Study}

The objectives of the study are classified into two categories including general and specific.

\subsubsection{General Objective}

The general objective of the study was to examine the contribution of agri-business lending on economic transformation in Rwanda, taking BPR Agri-Business lending in Rwamagana District as the case study.

\subsubsection{Specific Objectives}

The study was guided by the following specific objectives:

1.3.2.1 To assess the contribution of BPR's farm loans on economic transformation of Rwamagana District.

1.3.2.2 To evaluate the contribution of BPR's Agribusiness cash advances on economic transformation of Rwamagana District.

1.3.2.3 To assess the contribution of BPR's direct farm ownership loan on economic transformation of Rwamagana District.

\subsection{Research Questions}

The study was guided by the following research questions;

i. How does BPR's farm loans contribute to the economic transformation of Rwamagana District?

ii. What is the contribution of BPR's Agribusiness cash advances to the economic transformation of Rwamagana District?

iii. How does BPR's direct farm ownership loan to the economic transformation of Rwamagana District?

\section{Review of Literature \\ 2.0 Introduction}

This chapter reviews literature related to the study concepts. It provides a description of major concepts, a review of existing issues that have been explored and studied by different authors about the topic in question. It reviews how different books, reports relate to the topic and it is the theoretical framework of the study.

\subsection{Theoretical Literature}

\subsubsection{Agri-Business Lending Concept}

The concept of agri-business was conceived in 1957 at Harvard University with the book "A concept of Agri-business" published. It was, in the early stages of 1966, introduced in the country of the Philippines when the degree program in Agri-business Management (ABM) was introduced at the University of the Philippines. The first seminar in Advanced Agribusiness Management took place in Manila. "Agribusiness is a combination of all the manufacturing operations and those involved in the distribution of produce from farms, activities of production, distribution, storage, and processing of the commodities from the farm and the items derived from them". The agribusiness sector has witnessed a radical transformation as traditional operations in farming have become specialized more and become larger as well as the evolution of new industries (Loayza, 2017).

This transformation did not occur overnight but took place gradually as a response to various forces. Knowledge about how agribusiness came into existence leads to an easier understanding of the operation of the system today the manner in which it could change in the future. Agribusiness has three sectors which include the farm sector, which is aimed at the production of livestock, crops and other related products; the input sector that deals with the supply of those inputs that the farmers require to cultivate crops, raise livestock and other enterprises allied to them. Such include fertilizers, machinery, seeds, chemicals and fuel; and the product sector which includes aspects such as processing, storage, and marketing of the finished product. According to the Rwamagana District Development plan, 2010, agribusiness is, therefore, a combination of all activities or operations from the production of the farm supplies to the marketing of the finished product in a bid to achieve the objectives targeted.

Agribusiness is linked to both the sector of agriculture and the industrial sector, where the supply of farm inputs such as pesticides, fertilizers, post-harvest, and processing technologies as well as machines come from (Saad, Waraich, \&Ijaz, 2014; Nouman et al., 2013). It directs and suggests to the government and the private enterprise sub-sector development while contributing greatly to the economy. It is involved with different industrial and agricultural components, the influence one sector has on the other and the interdependence between the sector, whilst also influencing the process of decision making in public or private farms in the production aspect and that of selling (Barnard et al., 2016). Moreover, it deals with projects' strengths and weaknesses leading to viability in enterprises in a competing market. Agribusiness has a sense of 
market orientation and its general structure is vertical. It is comprised of government programs and policies regarding the cultivation of crops farm inputs or supplies, programs of research and extension, production from agriculture, and the consequent processing and also marketing of products from farms.

The agribusiness scopes take into account the daily food requirements at one's desired form, time and place. These come from hardworking and efficient business staff involved in input supply, activities of production of the food, and those who market the produce (Barnard, 2016). The whole system as a whole is known as agribusiness. The system is of late combining the various enterprise in the economy. This is through a combination of materials, labour, technology, and capital in a heterogeneous manner. The sector is dynamic and thus meets consumers' current demands in both local and worldwide markets continuously. The establishment of agribusiness has resulted in then reinforcement and marketing of agricultural products, infrastructural facility and the adoption of modernized technological production in the area (Loayza,2017). Agribusiness has a crucial role in the provision of linkages, both forward as well as backward. Agribusiness is a potential employment opportunity. It increases net gains and profits as it increases the value of the products.

\subsubsection{Credit Practices in Agri-Business Lending}

The credit concept is definable as an agreement based on a contract whereby the borrower is a recipient of something valuable and agrees to give back to the lender later on, sometimes at an agreed specified time. Credit, on the other hand, is an enterprise's or a person's capacity of borrowing; the potential of the debt to borrow. Debt is defined as an obligation to repay the borrower in the future. Because money is normally used as a standard of deferred payment, debt is usually a party's obligation to give back a specified sum and it comes into being through the granting of credit (Keneth, 2017).

Boreham (2018) classified credit facilities into the legion, depending upon the purpose of the study in which credit is being discussed. The study limits the examination to three of the more widely used classification as shown in Table 2.1.

Table 2.1: Classification of Credit

\begin{tabular}{|c|c|c|}
\hline As to use & As to maturity & $\begin{array}{c}\text { As to the type of } \\
\text { debtor }\end{array}$ \\
\hline a. Investment & a. Long-term & a. Public \\
\hline b. Commercial & b. Intermediate & b. Private \\
\hline c. Consumption & c. Short-term & \\
\hline & d. Demand & \\
\hline
\end{tabular}

Source: Boreham (2018)
It should be readily evident that these three classes are not totally unrelated. For example, investment credit may be subdivided by maturity and by type of debtor. Thus, investment credit is characteristically long-term credit, and it may be employed by either private or public debtors. Business firms' governmental bodies are typically the user of investment credit to acquire fixed assets like plant and equipment, which ordinarily have a relatively long life expectancy (Boreham, 2018). Furthermore, a corporation borrowing to build a factory knows its earnings will not be large enough to repay the loan in two or three years. For these reasons investment credit is long -term credit and is represented by bonds and notes having maturities of five or more years.

Commercial credit is used for current operations, an organization uses commercial credit to finance the production, manufacture, and marketing of goods (Bullivant, 2016). This type of credit is typically short -term repayment of the debt is made with the proceeds of the current sales of the firm, but it is self- liquidating only to the degree that current operations prove successful. Consumption credit defines the utilization or acquisition of consumer goods ranging from a loaf of bread to an automobile is financed by consumption credit (Storey, 2016). Long term credit is classified by maturity; credit has a maturity of five or more years when contracted is characterized as long term. This type of credit is customarily employed to acquire durable or fixed assets that when employed, provide earnings in small amounts relative to the debt over a period of years. Intermediate credit is credit that typically has a maturity of over one year and not more than five years is termed intermediate and short -term credit is credit that runs for less than a year is described as short term while demand credit is payable whenever the lender demands repayment by "calling the loan (Boreham,2018).

\subsubsection{The Role of Agri-Business Lending on Economic Transformation}

According to Johnson (2018), credit encourages investments, and attract private investment critically plays a vital role in lifting people out of poverty. Investment can best help to alleviate poverty in particular and uplift rural transformation and development in general. Agri-business lending helps local companies to raise equity capital and they further urged that private investment can play the following four major roles in economic transformation: New job creation: New job opportunities, as well as increased amounts of incomes, possess the multiplier kind of effect.

More disposable income leads to increased demand by consumers for goods and services and hence brings enhances business activities and job creation 
(Mellor, 2016). Increasing productivity and competitiveness: It makes workers more productive and more competitive. It leads to a reduction in crime rates and violence since a higher number of jobs lead to reduced unemployment rates and hence rural kids are engaged in work and not on the streets. These jobs mean that families have incomes and thus the society is safer to live in and eliminating rural exodus: rural population never leaves their villages to towns due to job creation (Johnson, 2018).

There are several needs for credit and finance in the development of agriculture as a principal activity, such as financial development for the introduction and extension of farming and processing operations; crop or making finance to provide funds when crops are harvesting and before they are processed for sale; the consumer credit to enable the farmer and village to purchase for himself and his family shelter, clothing and food when he cannot provide from his current substance activity and past savings; cultivation finance to assist with purchase of seed, fertilizer, insecticides and other recurrent farm inputs during that planting and growing season (Saad, et al., 2014). The rural economy needs a positive transformation through financing way.

For there is a need for the rural economy to be transformed and recapitalized in a bid to increase incomes from agriculture and also making a living from activities not involving agriculture. It is possible to achieve this through the presentation of new, current innovation and expanding upon the qualities of the economy of traditional rural Rwanda. (Mellor, 2016).

\subsubsection{Economic Transformation}

The economic transformation concept is considered to be wider than the growth of the economy. It is subsequently taken to bring forth the meaning of growth that incorporates change. It has a relationship to qualitative economic changes in goods, wants, incentives, knowledge, productivity, and institutions or the growth of the whole social system. It explains the underlying growth determinants such changes as structural and technological developments (Schumpeter, 2017). As a matter of fact, both decline and growth are embraced by the transformation of the economy. A country's economy may be on a growth path but neglect to develop because of joblessness, destitution and as such inequalities may persist because of lack of structural and technological changes. It is difficult for one to envision improvement and the nonattendance of monetary development in the lack of an increase in per capita output, more so in a rapidly growing population (Myrdal, 2018).

Moreover, economic translation brings out the structural economic transformation and as such: the reduction in dualism degree between the productivity of various regions; labor considered surplus is done away with and incorporated into employment that is highly productive, an increase in the share of services and manufacturing in GDP to respond to the changing demand composition and the increase in volume of transactions among industries due to the sector of manufacturing growing (Verma, 2017). The economy increases its diversity as well as its flexibility and adaptability due to the underlying social, institutional and political changes. Structural transformation is, therefore, an indispensable element in self-sustaining growth.

\subsubsection{Indicators of Economic transformation}

Economic transformation is measured mainly in four ways:

Gross National Product: Economic transformation could be measured by a country's increase in the real income in the economy calculated over a long time period.

Gross National Product per Capita: This measure is in relation to an expansion in the economy's real pay per capita over a long time period. Economists come to a common ground on this measure of economic transformation, which is as such the process whereby there is an increase in a country's real income per capita over a long time period (Verma, 2017). This is in line with stipulations such that the people living below the line of absolute poverty do not increase in number, and the income distribution does not get to the point of being unequal. The rate of population growth should be less than that of an increase in real per capita income for economic transformation to take place.

Welfare: There is also a tendency to measure economic transformation in the economic welfare viewpoint. It is regarded as the process in which an increase occurs in individuals' consumption of market goods and services. Richardson (2011) defines economic transformation as secular and sustained betterment material-wise, which in our consideration is reflected in greater goods and services flow.

Social Indicators: Certain economists have attempted to use social indicators in the measurement of economic transformation. Inputs such as the number of patients attended to by one doctor, a number of beds in the hospital or the standards of nutrition are considered. Others could be in the form of outputs such as improvements made in health services in the terms of rates of sickness, mortality rates of infants, etc. These indicators are often called basic or primary development needs. Basic needs lay focus on the alleviation of poverty through the provision of the primary needs of humans to the poor society (Richardson, 2011). The provision of primary human needs as education, health sanitation, housing, and water affects rates of poverty over a shorter time period while using lesser resources than the strategy of per capita GNP whose major goal is to automatically increase incomes and productivity 
of the poor population in the course of time. The provision of basic needs brings about a greater degree of productivity. The advantage of social indicators lies in their efforts to bring about ends, being the development of the human. Economic transformation is a means to these ends (Hicks, 2018).

\subsection{Theoretical Framework}

\subsubsection{Demand for Money Theory}

The theory of demand for money is the element that is principal in the theory of monetary economics and is vital in the 'macroeconomic theory' (Argy, 2013). Monetary demand emanates from two important money roles. The top one being that money acts as an exchange medium and the other being that money is a value store. Individuals and organizations thus prefer to keep some money in the form of cash while some as assets (Thompson, 2016). Two outlooks exist the scale outlook which states that demand for money is implicitly associated with the level of earnings; the substitution outlook associated with the assets which could act as money substitutes. Keynes associated money with a store of value since it is an asset where one can store wealth. Keynes believed that a person's entire wealth was in the form of bonds and money, using 'bonds' to describe the other risky assets aside from money.

So money holding was the only alternative to holding bonds. And the only determinant of an individual's portfolio choice was the interest rate on bonds (Johnson, 2017). This would affect an individual's decision to divide his portfolio into money and bonds. To Keynes, it costs money to hold money and the interest rate is an opportunity cost involved withholding money (Johnson, 2017). At high rates of interest, an individual loses a large sum by holding money or by not holding bonds. Thus, in Keynes' view, the demand for money is brought about by both interest rate and income.

According to the theory of Keynes, demand for money made an assumption that financial middlemen benefit the poor, regardless that they don't offer credit to them, because of the profitable opportunity of savings they offer (Johnson, 2017). This enables the intermediaries to collect the savings that are scattered, hence enabling the poor to seek credit from this pool of savings to start their own enterprises. According to Beck et al. (2017) many scholars agree that development in the sector of finance leads to financial opportunities for a majority of the population, with the benefits of the development far felt, even being felt by the poor. Jovanovich and Greenwood (1989) were however of the argument that there exists a u-shaped relationship between development of the financial sector and inequality in income distribution that is nonlinear and inverted: With the growth of the financial system, only a few rich firms and individuals gain access to funds for their projects, but later on more people get into the fold.

Some scholars have on the contrary doubted whether the development of the finance sector narrows or widens the gap between the wealthy and the poor (Argy, 2013). Some are heavily skeptical about the access by the poor to financial facilities at the early stage through the development of finance, which is broadening. Haber (2015) was of the idea that people with political connections and the rich would primarily be the beneficiaries of a development system of finance and this development may only succeed in increasing the capital amount of the chosen few. Feijen and Claessens (2017) state that the intermediaries in the finance system can greatly reduce the risk of individuals falling prey to the problem of poverty as well as aiding in coping with financial depressions through the provision of related services such as special credits, savings, and insurance.

\subsection{Conceptual Framework}

The conceptual framework guiding the study was as indicated in Figure 2.1.

\section{Research Methodology}

The independent variable for the study was agribusiness lending, whose predictors included farm loans, agriculture business cash advances, and direct farm ownership loans. Farm loans defined the direct operating loans given to farmers to help them cover equipment and other farm operating costs, agribusiness cash advances are short-term loans from banks for agricultural purposes, which direct farm ownership loans were offered by the bank as a product to help farmers to purchase the land and livestock that they needed to get started. These lending practices potentially contributed to the economic transformation of Rwamagana District through reduction of poverty levels, increased productivity and increase in agriculture cash flows. 


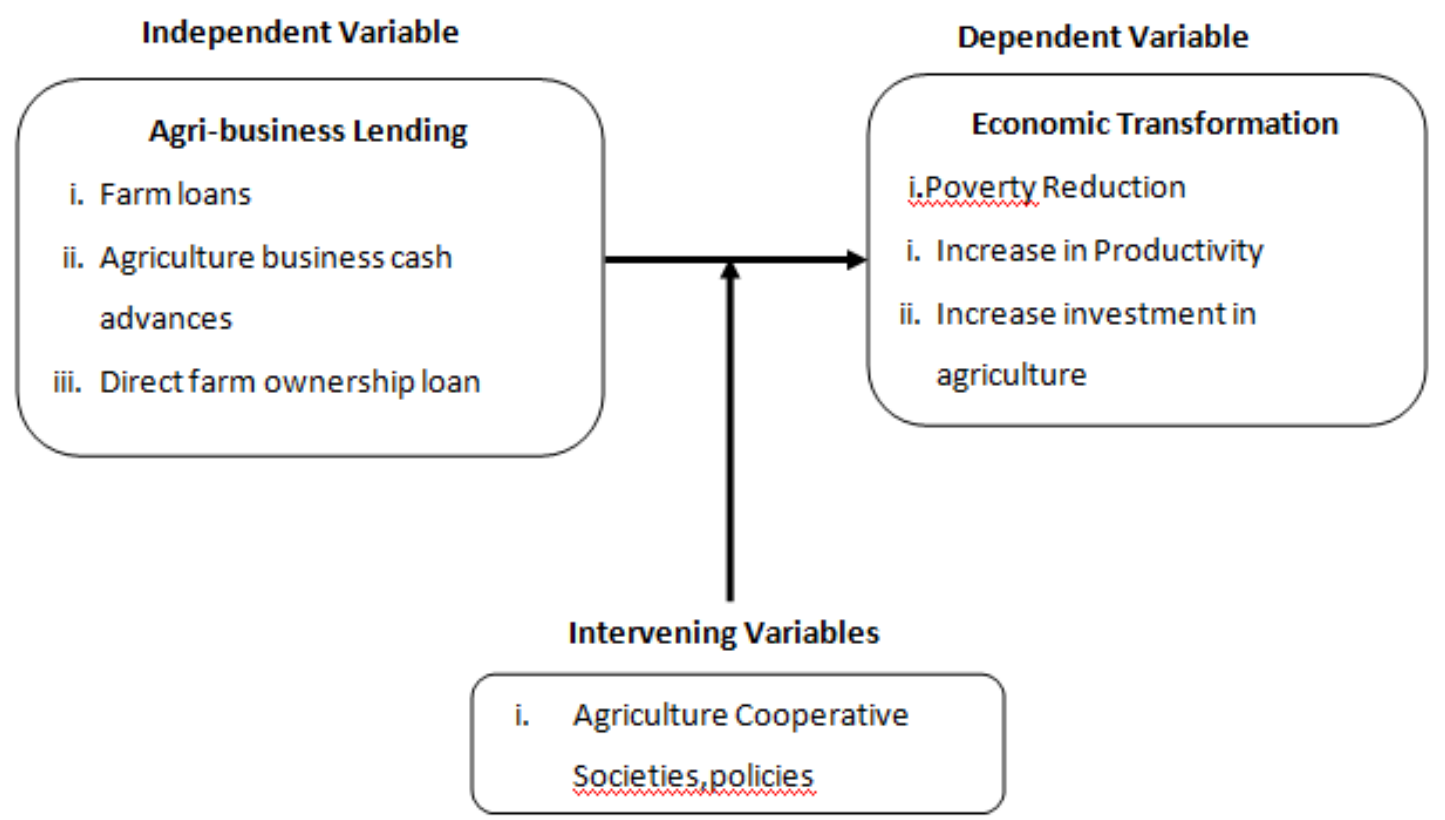

Figure 2.1: Conceptual Framework

Source: Researcher, 2019

\subsection{Target Population}

A study population is the total number of people or objects within a study's locality. The study's target population was 633 rice farmers servicing agribusiness loans at BPR Atlasmara Branch in Rwamagana District and who had indicated their area of cultivation as Cyaruhogo marshland and 4 credit managers located at the branch.

\subsection{Sample Design}

\subsubsection{Sample size}

BOUCHAR formula was used to calculate the sample size. Mbarubukeye (2008)stipued that when all population under study is less than 1,000,000 the estimated error is $10 \%$ corresponding to 96 individuals. Therefore, 633 people constitute the population in the study and sample was calculated as:

$\mathrm{Nc}=\frac{\mathrm{n}}{1+\frac{\mathrm{n}}{\mathrm{N}}}=\frac{\mathrm{n}}{\frac{\mathrm{N}+\mathrm{n}}{\mathrm{N}}}=\frac{\mathrm{N} \cdot \mathrm{n}}{\mathrm{N}+\mathrm{n}}$ Hence N. $\mathrm{c}=\frac{\mathrm{N} \cdot \mathrm{n}}{\mathrm{N}+\mathrm{n}}$

Where: N.c: Sample without error

N: Total Population under study of 633 farmers include four in charges of credit.

$\mathrm{n}$ : The proposal infinite sample by the formulae estimated to 96

Then using N.c $=\frac{\mathrm{N} . \mathrm{n}}{\mathrm{N}+\mathrm{n}}$; calculation becomes: $\frac{633 \times 96}{633+96}=84$

\subsubsection{Data Collection Instruments 3.4.1.1 Questionnaire}

A questionnaire can be defined as a set of related questions designed to collect information from a respondent. A group of or sequence of questions designed to elicit information upon a subject) or a sequence of subjects from an informant. Nigel (2012) explains a questionnaire as a survey instrument intended for in mated or self-administered survey. It is composed of open -ended and closeended questions. Open-ended questionnaire is a set of questions set to give interviewee a chance to express his or her opinions. With no limitation through the information obtained is at time not relevant to the topic.

\subsubsection{Interview schedule}

An interview schedule is a document containing questions that guide interviews. Interviews are faceto-face interactions between researchers and study participants, with one party providing information regarding the study. According to Bugingo (2015), interviews entail conversations through which researchers get information from interviewees, who are respondents in a study. Interview schedules were used to document information from credit officers in the district. 
4. Presentation of Findings

Table 4.1: Contribution of BRP's direct farm ownership loan to Economic Transformation

\begin{tabular}{|c|c|c|c|c|c|c|c|c|}
\hline & $\mathrm{N}$ & \multirow{2}{*}{$\begin{array}{l}\text { Strongly } \\
\text { Agree }\end{array}$} & \multirow[b]{2}{*}{ Agree } & \multirow[b]{2}{*}{ Neutral } & \multirow[b]{2}{*}{ Disagree } & \multirow{2}{*}{$\begin{array}{l}\text { Strongly } \\
\text { Disagree }\end{array}$} & \multirow[b]{2}{*}{ Mean } & \multirow{2}{*}{$\begin{array}{c}\text { Std. } \\
\text { Deviation }\end{array}$} \\
\hline & Valid & & & & & & & \\
\hline Poverty reduction & 84 & 32 & 39 & 13 & - & - & 4.2262 & .70028 \\
\hline Increase in productivity & 84 & 40 & 2 & 10 & 5 & 2 & 4.1667 & 1.01594 \\
\hline Increased asset acquisition & 84 & 15 & 27 & 23 & 13 & 6 & 3.3810 & 1.16065 \\
\hline $\begin{array}{l}\text { Increase in agriculture cash } \\
\text { flows }\end{array}$ & 84 & 29 & 35 & 12 & 6 & 2 & 3.9881 & .99993 \\
\hline Increase in Savings & 84 & 30 & 46 & 4 & 3 & 1 & 4.2024 & .78816 \\
\hline Enhanced health and nutrition & 84 & 35 & 31 & 11 & 3 & 4 & 4.0714 & 1.06178 \\
\hline Improvement of food security & 84 & 22 & 34 & 20 & 6 & 2 & 3.8095 & .98759 \\
\hline $\begin{array}{l}\text { Increase in employment } \\
\text { opportunities }\end{array}$ & 84 & 51 & 14 & 11 & 3 & 5 & 4.2262 & 1.17557 \\
\hline Improved Infrastructure & 84 & 33 & 34 & 12 & 4 & 1 & 4.1190 & .91051 \\
\hline
\end{tabular}

Source: Primary Data, 2019

As indicated in Table 4.13, respondents strongly agreed that BPR's direct farm ownership loan had contributed to poverty reduction (mean 4.22 , sdv .70 ); increased productivity (mean 4.16, sdv 1.01), increased savings (mean 4.20, sdv .78); enhanced health and nutrition (mean 4.07, sdv 1.06); increased employment opportunities (mean 4.22, sdv 1.17); and improved infrastructure (mean 4.11, sdv .91). Respondents recorded neutral responses regarding the contribution of direct farm ownership loan on economic transformation of the district. Economic transformation indicators that attracted neutral Table 4.2: Correlation Analysis responses included; increase in asset acquisition (mean 3.38, sdv 1.16); Increase in agriculture cash flows (mean 3.98, sdv .99); and improvement of food security (mean 3.80, sdv .98).

\subsubsection{Relationship Between BRP's Agri-Business} Lending and Economic transformation

The fourth research objective was to examine the relationship between BRP's agri-business lending and economic transformation of Rwamagana District. Correlation and regression analyses were done to determine the relationships and recorded.

\begin{tabular}{|c|c|c|c|c|c|c|c|}
\hline & & $\begin{array}{l}\text { Farm } \\
\text { Loans }\end{array}$ & $\begin{array}{l}\text { Agri-business } \\
\text { cash advances }\end{array}$ & $\begin{array}{c}\text { Direct farm } \\
\text { ownership } \\
\text { loan }\end{array}$ & $\begin{array}{c}\text { Poverty } \\
\text { Reduction }\end{array}$ & $\begin{array}{l}\text { Increase in } \\
\text { Productivity }\end{array}$ & $\begin{array}{l}\text { Increase in } \\
\text { agriculture } \\
\text { cash flows }\end{array}$ \\
\hline \multirow[t]{3}{*}{ Farm Loans } & Pearson Correlation & 1 & $.317^{* *}$ & $.350^{*}$ & $.972^{* * *}$ & $.254^{*}$ & $.265^{*}$ \\
\hline & Sig. (2-tailed) & & .000 & .010 & .000 & .019 & .042 \\
\hline & $\mathrm{N}$ & 84 & 84 & 84 & 84 & 84 & 84 \\
\hline \multirow{3}{*}{$\begin{array}{l}\text { Agri-business } \\
\text { cash advances }\end{array}$} & Pearson Correlation & $.317^{* *}$ & 1 & $.211^{*}$ & $.747^{*}$ & $.971^{* * *}$ & $.945^{* *}$ \\
\hline & Sig. (2-tailed) & .000 & & .045 & .036 & .000 & .000 \\
\hline & $\mathrm{N}$ & 84 & 84 & 84 & 84 & 84 & 84 \\
\hline \multirow{3}{*}{$\begin{array}{l}\text { Direct farm } \\
\text { ownership loan }\end{array}$} & Pearson Correlation & $.350^{*}$ & $.211^{*}$ & 1 & $.572^{*}$ & $.579^{* * *}$ & $.775^{*}$ \\
\hline & Sig. (2-tailed) & .010 & .045 & & .015 & .000 & .032 \\
\hline & $\mathrm{N}$ & 84 & 84 & 84 & 84 & 84 & 84 \\
\hline \multirow[t]{3}{*}{ Poverty Reduction } & Pearson Correlation & $.972^{* *}$ & $.747^{*}$ & $.572^{*}$ & 1 & $.405^{* *}$ & $.908^{*}$ \\
\hline & Sig. (2-tailed) & .000 & .036 & .015 & & .000 & .013 \\
\hline & $\mathrm{N}$ & 84 & 84 & 84 & 84 & 84 & 84 \\
\hline Increase & Pearson Correlation & $.254^{*}$ & $.971^{* *}$ & $.579^{* *}$ & $.405^{* *}$ & 1 & $.520^{*}$ \\
\hline \multirow[t]{2}{*}{ Productivity } & Sig. (2-tailed) & .019 & .000 & .000 & .000 & & .017 \\
\hline & $\mathrm{N}$ & 84 & 84 & 84 & 84 & 84 & 84 \\
\hline \multirow[t]{3}{*}{$\begin{array}{l}\text { Increase } \\
\text { agriculture } \\
\text { flows }\end{array}$} & Pearson Correlation & $.265^{*}$ & $.945^{* *}$ & $.775^{*}$ & $.908^{*}$ & $.520^{*}$ & 1 \\
\hline & Sig. (2-tailed) & .042 & .000 & .032 & .013 & .017 & \\
\hline & $\mathrm{N}$ & 84 & 84 & 84 & 84 & 84 & 84 \\
\hline
\end{tabular}

The findings suggested positive correlations between farm loans and; poverty reduction $\left(r .972^{* *}, \mathrm{p} .000\right)$, increase in productivity ( $\left.r .254^{*}, \mathrm{p} .019\right)$, and Increase in agriculture cash flows $\left(r .265^{*}, \mathrm{p} .045\right)$. All the correlations were statistically significant given that the $\mathrm{p}$ value was $<0.05$ and $<0.01$. The findings suggested that an increase in the number of people 
accessing and using farm loans effectively would translate to poverty reduction, increase in productivity, and Increase in agriculture cash flows. There were positive correlations between Agribusiness cash advances and; poverty reduction ( $r$ $\left..747^{*}, \mathrm{p} .036\right)$, increase in productivity $\left(r .971^{* *}, \mathrm{p}\right.$ $.000)$, and Increase in agriculture cash flows $\left(r .945^{* *}\right.$, $\mathrm{p}$.000). All the correlations were statistically significant given that the $\mathrm{p}$ value was $<0.05$ and $<$ 0.01 . The findings suggested that an increase in the number of people accessing and using Agri-business cash advances effectively would translate to poverty reduction, increase in productivity, and Increase in agriculture cash flows.

There were positive correlations between Direct farm ownership loan and; poverty reduction $\left(r .572^{*}, \mathrm{p} .015\right)$, increase in productivity $\left(r .579^{* *}, \mathrm{p} .000\right)$, and Increase in agriculture cash flows ( $\left.r . .775^{*}, \mathrm{p} .032\right)$. All the correlations were statistically significant given that the $\mathrm{p}$ value was $<0.05$ and $<0.01$. The findings suggested that an increase in the number of people accessing and using Direct farm ownership loan effectively would translate to poverty reduction, increase in productivity, and Increase in agriculture cash flows.

\section{Summary, Conclusions Recommendations}

\subsection{Introduction}

Chapter five presents the study's summary of research findings, conclusions, and offers relevant solutions. The final section of the chapter captures the researcher's suggestion for future studies.

\subsection{Summary of Findings}

5.1.1 Contribution of Farm Loans on Economic Transformation

The first research objective was to assess the contribution of BPR's farm loans on economic transformation of Rwamagana District. Respondents were asked to document their opinions regarding the contribution of BRP's farm loans to economic transformation of Rwamagana district using a scale of $1-5$. Respondents strongly agreed that BPR's farm loans had contributed to the economic transformation of Rwamagana by; reducing poverty (mean 4.27, sdv .78); increasing productivity (mean 4.39, sdv .83); increasing asset acquisition (mean 4.29, sdv.65); increasing cash flows (mean 4.29; sdv .80 ); increasing savings (mean 4.34, sdv .64); enhancing health and nutrition (mean 4.14, sdv .99); improving food security (mean 4.32; sdv .73); increasing employment opportunities (mean 4.50, sdv .69); and improving infrastructure (mean 4.17; sdv 1.16) (see Table 4.9).

\section{ISSN 2455-6378}

5.1.2 Contribution of Agri-business Cash Advances on Economic Transformation

The second research objective was to evaluate the contribution of BPR's agribusiness cash advances on economic transformation of Rwamagana District. Respondents were asked to document their responded regarding their ability to access cash advances for agri-business purposes. Most of the respondents $(82.1 \%)$ suggested that they had access to BPR's agribusiness cash advances while $17.9 \%$ could not access the facilities. Most of the respondents were thus able to access the facilities indicating high financial inclusion which would translate to farmers acquiring credit facilities to finance their own agricultural activities and hence high productivity and improved social and economic activities in the region (see Table 4.10).

Respondents strongly agreed that BPR's agribusiness cash advances had contributed to poverty reduction (mean 4.22, $\mathrm{sdv} .82$ ); increase in productivity (mean 4.20, sdv .88), increase in asset acquisition (mean 4.53, sdv .54); Increase in agriculture cash flows (mean 4.33, sdv .81); increase in savings (mean 4.59, sdv .66); enhanced health and nutrition (mean 4.42, sdv .82); improvement of food security (mean 4.57, sdv .62); increase in employment opportunities (4.57, sdv .60); and improve in infrastructure (mean 4.35; sdv .78) (see Table 4.11).

\subsubsection{Correlation Analysis}

The fourth research objective was to examine the relationship between BRP's agri-business lending and economic transformation of Rwamagana District. Correlation and regression analyses were done to determine the relationships and recorded. A Pearson correlation analysis was conducted to investigate the relationship between the independent variable, agribusiness lending (farm loans, Agribusiness cash advances, and direct farm ownership loan) and the dependent variable, economic transformation (poverty reduction, increased in productivity, Increase in agriculture cash flows).

The findings suggested positive correlations between farm loans and; poverty reduction $\left(r .972^{* *}, \mathrm{p} .000\right)$, increase in productivity $\left(r .254^{*}, \mathrm{p} .019\right)$, and Increase in agriculture cash flows $\left(r .265^{*}, \mathrm{p} .045\right)$. All the correlations were statistically significant given that the $\mathrm{p}$ value was $<0.05$ and $<0.01$. There were positive correlations between Agri-business cash advances and; poverty reduction $\left(r .747^{*}\right.$, p .036), increase in productivity $\left(r .971^{* *}, \mathrm{p} .000\right)$, and Increase in agriculture cash flows ( $\left.r . .945^{* *}, \mathrm{p} .000\right)$. All the correlations were statistically significant given that the $p$ value was $<0.05$ and $<0.01$. There were positive correlations between Direct farm ownership loan and; poverty reduction $\left(r .572^{*}, \mathrm{p} .015\right)$, increase in productivity $\left(r .579^{* *}, \mathrm{p} .000\right)$, and Increase in agriculture cash flows $\left(r . .775^{*}, \mathrm{p} .032\right)$. All the 
correlations were statistically significant given that the $\mathrm{p}$ value was $<0.05$ and $<0.01$ (see Table 4.14).

\subsection{Conclusions}

Agri-business financing is accepted to be a significant fixing in cultivating exercises as satisfactory arrangement of assets to famers makes all exercises in the ranch conceivable and prompts increment in yield. In light of this recognition, the examination was fundamentally to look at the contribution of agri-business lending on economic transformation of Rwanda, taking BPR Farm loans in Rwamagana District as the case study. From the outcomes got, there existed a critical connection between agri-business lending and economic transformation in the region. Thus, the study concluded that BPR agri-business lending significantly and positively with the agricultural production and poverty eradication, which lead to the economic transformation of Rwamagana District.

\subsection{Recommendations}

The accompanying policy suggestions emanated from the discoveries of this examination:

i. BPR and other financial related foundations should make particular credit plans and projects by remembering their objective clients' characters.

ii. The lack of adequate government structure to fund agri-business activities calls for proper funding by all involved stakeholders. To this end, there is need for the government to assurance loans are given to farmers as this will urge the banks to loan more to farmers

iii. The beneficial outcome of business banks' credit to horticulture on farming generation calls for more assignment of credit to the agrarian area in Rwanda. This can be accomplished by the National Bank of Rwanda bringing down the financing cost charged on ranchers for cash obtained with the end goal of agrarian production.

\section{Acknowledgements}

The completion of this research project was made a success due to the guidance and support of various people. First I am highly indebted to my supervisor Dr. Claude Rusibana, for his special guidance, his comments, criticism and suggestions during this research work that helped me to improve always. I am greatly thankful to the lecturers in the department of finance and accounting who greatly shaped my ideas by investing their efforts to ensure that the completion of this project was in time. My sincere gratitude is conveyed to my wife Mme. GahongayireVestine Aliyah for sending me to school and for her responsible parental care and devotion in accepting the opportunity costs of my absence during studies.

\section{References}

[1] Access to Finance Rwanda. (2012). FinScope Rwanda 2012 - BNR. Accessed on https://www.bnr.rw/fileadmin/user_upload/ 2012.pdf

[2] ADB. (2010). Agriculture and Rural Development Sector Bank Group Policy by the African Development Fund.

[3] Amin, E. (2015).Social sience research conception, methodology and analysis. London: Companies, Inc.

[4] Andreassen, B. A., Marks, S. P., \&Sengupta, A. (2010). Freedom from poverty as a human right: economic perspectives. UNESCO.

[5] Argy, V. (2013). International macroeconomics: theory and policy. Routledge.

[6] Awotide, B. A., Abdoulaye, T., Alene, A., \&Manyong, V. M. (2015). Impact of access to credit on agricultural productivity: Evidence from smallholder cassava farmers in Nigeria (No. 1008-2016-80242).

[7] Barnard, F. L., Akridge, J. T., Dooley, F. J., Foltz, J. C., \& Yeager, E. A. (2016). Agribusiness management. Routledge.

[8] Beck, T., Demirgüç-Kunt, A., \& Levine, R. (2017). Finance, inequality and the poor. Journal of economic growth, 12, 27-49.

[9] Bolarinwa, K. K., \&Fakoya, E. O. (2011). Impact of Farm Credit on Farmers Economic Status in Ogun State Nigeria. Journal of social Sciences, 26(1), 67-71.

[10] Boreham, S.S. (2018). Credit worthiness. White print Washington, D.C

[11]Bugingo, E. (2015). The meaning of scientific reseach mothodology.Butare: National University of Rwanda.

[12] Bullivant, G. (2016). Credit management. Routledge.

[13] Capello, R., \& Nijkamp, P. (2015). Handbook of regional growth and development theories. Edward Elgar Publishing.

[14] Chandio, A. A., Jiang, Y., Wei, F., Rehman, A., \& Liu, D. (2017). Famers' access to credit: Does collateral matter or cash flow matter? -Evidence from Sindh, Pakistan. Cogent Economics \& Finance, 5(1), 1369383.

[15] Chase, E., \&Bantebya-Kyomuhendo, G. (2014). Poverty and shame: Global experiences. OUP Oxford.

[16] Claessens, S., \&Feijen, E. (2017). Financial sector development and the millennium development goals. World Bank Publications. 
[17] Georges, B. (2018). Data analysis. University of Rochester

[18]Haber, S. (2015). Mexico's experiments with bank privatization and liberalization, 1991-2003. Journal of Banking \& Finance, $29,2325-2353$

[19] Johnson, H. G. (2017). Macroeconomics and monetary theory. Routledge.

[20] Johnson, T.(2018). Role of credit in poverty reduction. Probablica, Paris.

[21] Jolliffe, D. (2014). A measured approach to ending poverty and boosting shared prosperity: concepts, data, and the twin goals. World Bank Publications.

[22] Keneth, D. (2017). Financial Planning in Agriculture. Wind Star

[23]Larry, B. C. (2011). Research design. Prentice Hall, New York.

[24] Loayza, N.V.(2017).The Economics of the Informal Sector: A Simple Model and Some Empirical Evidence from Latin America. New York

[25]Lucas, R. (2018). On the mechanics of economic transformation. Econometric Society Monographs, 29, 61-70.

[26] Mbarubukeye C. (2008). Benefits and challenges for the establishment of BPR Ltd's in Rwanda. Kigali. Kigali, Rwanda

[27] Mellor, J. W. (2016). The economics of agricultural development

[28] Mithani, P.(2012). Introduction a l'économie de développement. Probablica, Paris.

[29] Myrdal, D. (2018). Economic Theory and Underdeveloped Region. New York: Free Press.

[30] Nigel, B.(2012).Sampling for Internet Survey .An examination of respondent selection for internet reseach.Journal of the Market Reseach Socierty, 387-395.

[31] Nouman, M., Siddiqi, M., Asim, S., \& Hussain, Z. (2013). Impact of economic characteristics of farmers on access to agricultural credit. Sarhad Journal of Agriculture, 29(3), 469-476.

[32] Programmes des Nation Unies pour Development. (2014). La pauvreté humaine; Rapport sur la pauvreté dans le Monde, 2000. Paris : Print Room

[33] Reyes, A., Lensink, R., Kuyvenhoven, A., \& Moll, H. (2012). Impact of access to credit on farm productivity of fruit and vegetable growers in Chile (No. 1007-201679549).
[34] Richardson, M. (2011). Economic transformation Strategies, Landon: Press House.

[35] Saad, A., Waraich, I. A., \&Ijaz, M. (2014). Economic Effects of Microfinance on Agricultural Sector: An Analysis of Farmer's Standard of Life in Multan. International Review of Management and Business Research, 3(3), 1671.

[36] Saleem, M. A., Jan F. A., and Khattak, R. M. 2010. Impact of Landholding and farmers characteristics in Obtaining Credit for Agricultural Productivity in District D.I.Khan. Abasyn. J. Soc. Sci. 3(2):177193.

[37] Saqib, S. E., Kuwornu, J. K., Panezia, S., \& Ali, U. (2018). Factors determining subsistence farmers' access to agricultural credit in flood-prone areas of Pakistan. Kasetsart Journal of Social Sciences, 39(2), 262-268.

[38] Schumpeter, J. A. (2017). Theory of economic transformation. Routledge.

[39] Stone, R., Temu, A., Kalisa, M. \& Cabello, M. (2011). Rural and Agricultural Financial Services Strategy: Ministry of Agriculture and Animal Resources and DFID Rwanda. Rwanda Rural and Agricultural Financial Services Strategy, Oxford Policy Management. Accessed on www.minecofin.gov.rw/.../Rural_and_Agric ultural_Financial_Services_Strategy.pdf

[40] Storey, D. J. (2016). Understanding the small business sector. Routledge.

[41] Thompson, N. (2016). Portfolio theory and the demand for money. Springer.

[42] Verma, R. (2017). Gross National Happiness: meaning, measure and degrowth in a living development alternative. Journal of Political Ecology, 24(1), 476-490.

[43] Walker, R., Kyomuhendo, G. B., Chase, E., Choudhry, S., Gubrium, E. K., Nicola, J. Y., ... \& Ming, Y. (2013). Poverty in global perspective: is shame a common denominator?.Journal of Social Policy, 42(2), 215-233.

[44] Word Bank Group. (2008). Annual report. Kigali.

[45] World Bank. (2006). Poverty reduction and the World Bank progress and challenge. Washington

[46] World Bank. (2018). Agriculture Finance \& Agriculture Insurance. The World Bank. Accessed on http://www.worldbank.org/en/topic/financia lsector/brief/agriculture-finance 